\title{
Sensory acceptance and postharvest quality of a new hybrid of citrus: TMxLP 16
}

\author{
Camilla de Andrade Pacheco ${ }^{1}$, Evandro Henrique Schinor ${ }^{2}$, Fernando Alves de Azevedo ${ }^{3}$, \\ Gabriel Danilo Shimizu1, Marinês Bastianel ${ }^{3}$ \& Mariângela Cristofani-Yaly $^{3}$
}

\section{SUMMARY}

Planting new types of sweet orange is an interesting alternative for the Brazilian citrus growers as this domestic market continues to grow. Thus, the aim of this study was to evaluate the acceptance and storage of a new hybrid between Murcott tangor and Pêra sweet orange, TMxLP 16. The treatments tested were: storage of fruits with and without wax, at room temperature $\left(21 \pm 2{ }^{\circ} \mathrm{C}\right.$ and relative humidity $(\mathrm{RH})=60 \pm 5 \%)$ and at cold temperature $\left(10 \pm 2{ }^{\circ} \mathrm{C}\right.$ and $\left.\mathrm{RH}=90 \pm 5 \%\right)$. Before storage samples were sensory tested for acceptance. Physicochemical qualities of the fruit and juice [mass, seeds, juice yield, acidity, soluble solids and ratio of soluble solids to titratable acidity (SS/TA)] were performed, before and after storage. The TMxLP 16 hybrid has an appropriate mass required for sale per fruit, a suitable juice yield, and early-mid season maturation, with high sensory acceptance, all characteristics which meet the standards required by the Brazilian consumer market. The results of this investigation showed that fruit stored at room temperature lost considerable weight. These results indicate a trend towards a loss of quality in fruits stored under ambient conditions and not coated with wax, which reaffirms the need for the use of refrigeration and waxy coverage for postharvest conservation of citrus fruits in natura.

Index terms: conservation, sensorial analysis, test of acceptation, citrus.

\section{Aceitação sensorial e qualidade pós-colheita de um novo híbrido de citros: TMxLP 16}

\section{RESUMO}

O plantio de novos tipos de laranja doce é uma alternativa interessante para os produtores de citros brasileiros, já que o mercado interno é crescente. Assim, o objetivo deste estudo foi avaliar a aceitação e armazenamento de um novo híbrido entre tangor Murcott e larnaja Pêra, o TMxLP 16. Os tratamentos testados foram: armazenamento de frutos com e sem cera, à temperatura ambiente $\left(21 \pm 2{ }^{\circ} \mathrm{C}\right.$ e humidade relativa $\left.(\mathrm{HR})=60 \pm 5 \%\right)$ ea temperatura fria $\left(10 \pm 2{ }^{\circ} \mathrm{C}\right.$ e $\left.\mathrm{RH}=90 \pm 5 \%\right)$. Antes do armazenamento as amostras foram testadas sensorialmente para a aceitação. A qualidade físico-química dos frutos e do suco (massa, sementes, rendimento de suco, acidez, sólidos solúveis e proporção de sólidos solúveis à acidez titulável (SS/TA), foram avaliadas, antes e após o armazenamento. O híbrido TMxLP 16 tem uma massa adequada para a venda in natura, um elevado

\footnotetext{
${ }^{1}$ Departamento de Agronomia, Universidade Estadual de Londrina - UEL, Londrina, PR, Brasil

${ }^{2}$ Departamento de Biotecnologia Vegetal, Universidade Federal de São Carlos - UFSCar, Araras, SP, Brasil

${ }^{3}$ Centro APTA Citros Sylvio Moreira, Instituto Agronômico - IAC, Cordeirópolis, SP, Brasil

Corresponding author: Camilla de Andrade Pacheco, Departamento de Agronomia, Universidade Estadual de Londrina - UEL, Rodovia Celso Garcia Cid - Pr 445 Km 380, CP 6001, CEP 86051-990, Londrina, PR, Brasil. E-mail: camilla_andrade@yahoo.com.br
} 
rendimento de suco e maturação precoce a meia-estação, com alta aceitação sensorial; características que atendam aos padrões exigidos pelo mercado consumidor brasileiro. Os resultados mostraram que os frutos armazenados à temperatura ambiente perderam massa de forma considerável. Estes resultados indicam uma tendência à perda de qualidade nos frutos armazenados em condição ambiente e não revestidos com cera, o que reafirma a necessidade de uso de refrigeração e cobertura de cera para a conservação pós-colheita de frutos de citros in natura.

Termos de indexação: conservação, análise sensorial, teste de aceitação, citros.

The orange is among one of the most appreciated fruits by Brazilian consumers, and as a result a lot of research related its genetic improvement has been made. This includes obtaining hybrids with resistance or tolerance to pests and diseases, and with trees with medium to small fruit size, high productivity and high quality fruits. In this context, the hybrid TMxLP 16, resulting from a cross between Murcott tangor (TM) and Pera sweet orange (LP), proved to be resistant to Alternaria, brown spot and citrus chlorosis variegated (CVC). It also has rounded to oval fruit shape, which is desirable in for commercial oranges, marketed in both the in natura (fresh fruit) and processed (juice) groups (Schinor et al., 2010).

The citrus juice processing industries analyze physical and chemical parameters like acidity, $\mathrm{pH}$, ratio, soluble solids, ascorbic acid, essential oil, color and viscosity, to not only to control the product quality, but also to meet the requirements set by consumers. However, these parameters do not provide sufficient data to evaluate acceptance of a new orange hybrid by the consumer, so a combination of the physical and chemical analyses and a sensory analysis need to be investigated to provide the relevant data to better define consumer expectations (Janzantti et al., 2011).

New hybrids require an essential sensory analysis in order to verify their acceptance by consumers. This analysis is done through the use of the human testers and includes: sight, taste, smell, hearing and skin sensitivity. Thus, the sensory analyses are used to assess its quality, acceptability by consumers and in research for the development of new products (Beckley et al., 2007).

The conservation of fruits and vegetables after harvest is also important; the fruit should reach the consumer without changes in their nutritional value, appearance and flavor. Thus, only products harvested at the appropriate degree of maturity and with good quality should be conserved. In addition, the resistance of each product to cold storage allows the proper storage of fruits by extending their period of commercialization prior to consumption (Agostini et al., 2014).
This study aimed to evaluate the physical, chemical and sensory quality of fruits of hybrid TMxLP 16, in different storage environments and over different time periods in storage, as well as to verify their acceptability by consumers.

Fruits from the hybrid TMxLP 16 were collected in May of 2012, in Cambuhy Farm, in Matão, Sao Paulo State, Brazil. The plants were three years old, planted at $6.0 \times 4.0 \mathrm{~m}$ tree spacing and were irrigated. After harvest, the fruit were disinfected with a solution of sodium hypochlorite $5 \%$, then dried. The fruit were then subjected to the treatments which included storage with and without wax, and 1 . stored at $10 \pm 2{ }^{\circ} \mathrm{C}$ and $90 \pm 5 \%$ relative humidity (RH) and 2. at $21 \pm 2{ }^{\circ} \mathrm{C}$ and $60 \pm 5 \%$ RH. The fruits coated with wax received an application of wax in commercial use associated with fungicide. The physicochemical analysis, were performed weekly until 30 days after the beginning of storage.

The following variables were assessed before the storage period: a) mass loss, which was determined by making the difference between the initial mass and that obtained each day of analysis, being the results expressed as percent (\%); b) seeds, by direct count; c) titratable acidity, obtained by titration with a standardized solution of $0.3125 \mathrm{~N}$ of $\mathrm{NaOH}$, using phenolphthalein as an indicator, with estimates based on volume; d) soluble solids determined by a refractometer; e) ratio calculated with the relationship soluble solids/acidity.

The experiment was completely randomized and designed in subdivided plots with three replications. An amount of 10 fruit per repetition were used for quantifying the mass loss and four fruits per repetition for other physicochemical analysis. There were three factors being assessed: time ( $\mathrm{x} 4$ weeks), storage (ambient and $10{ }^{\circ} \mathrm{C}$ ) and coating (with and without wax). The data were subjected to analysis of variance and regression analyses.

The sensory acceptance test was done by a group of 50 individuals of different age groups and belonging to different social classes. Data were collected through individual chips, using a nine-point hedonic scale, ranging from 'dislike extremely' to 'like extremely' as well as 
questions about what the taster most liked or disliked in the sample, according to methodology used in Behrens et al. (1999). There was also a structured five-point scale for purchase intent, ranging from 'definitely would buy' to 'definitely would not buy'. The samples were served at room temperature in a paper plate, being encoded with four different letters, and the judges rated the overall appearance of the fruit (appearance, peel color, texture, firmness, ease of debarking) and its inner aspect (consistency, aroma, and flavor). To carry out this research, ethical approval was given by the Ethics Committee on Human Research of Federal University of São Carlos (UFSCar), Protocol No. 2305.0.000135-11. All participants of this study signed a consent form before participating in the study (196/96 - National Health Council).

The fruits used in the tests were at the optimum ripeness, with appropriate values for acidity, soluble solids, and, consequently, ratio ( $>10)$, thus making them apt for commercialization and consumption (Table 1).

The hybrid TMxLP 16 obtained high acceptance rate with $93 \%$ of approval, $4 \%$ of rejection and $2 \%$ of indifference; with $88 \%$ of the testers liking the fruit moderately to extreme and only $6 \%$ chose the category 'dislike slightly' on the hedonic scale. Thus, the sum of the positive characteristics evaluated, such as flavor, firmness, aroma and internal consistency, contributed satisfactorily for an intention to purchase of $98 \%$. One feature less appreciated by the panel was the large number of seeds, around 22 per fruit (Figure 1 and Table 1).

Testing of the different storage periods found that after 35 days, the fruits stored at room temperature lost more mass than the fruits maintained in low temperature (Figure 2); there was no difference with wax use. In the group of fruits stored at room temperature, the mass losses occurred due to water loss by transpiration, caused by the difference in vapor pressure between the fruit and the air, and the metabolic processes of respiration. In fruits stored at $10{ }^{\circ} \mathrm{C}$, there was lower weight loss due to a reduction in the respiration rate at the lower temperature (Lima \& Durigan, 2000). A similar result was observed in Agostini et al. (2014), where they studied the postharvest quality of Champagne oranges with different coatings and stored at different temperatures, and in Nascimento et al. (2006) who found that higher weight loss from Pêra oranges stored at room temperature compared to fruits stored under refrigeration at $10{ }^{\circ} \mathrm{C}$.

The acidity of the fruits decreased during the storage period (Figure 3), mainly in the fruits stored at room

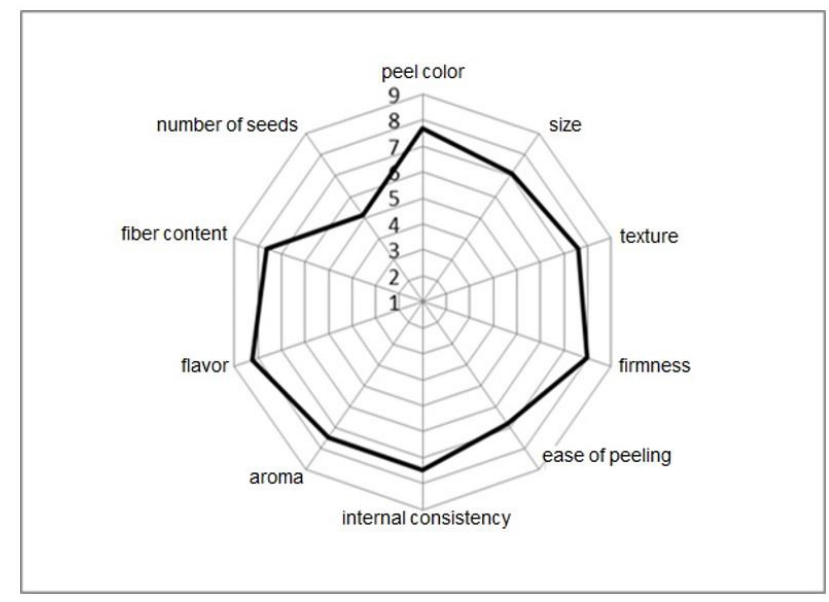

Figure 1. The most and least appreciated sensory characteristics of the fruits of hybrid TMxLP 16 by tasters, Cordeirópolis, SP, Brazil (2012).



Figure 2. Mass loss (\%) of the hybrid TMxLP 16 fruits stored under room temperature or refrigeration for 35 days.

Table 1. Physicochemical characteristics of the hybrid TMxLP 16 fruits (Centro APTA Citros Sylvio Moreira, IAC, Cordeirópolis, SP, Brazil, 2012)

\begin{tabular}{ccccccc}
\hline Variety & mass $(\mathrm{g})$ & $\begin{array}{c}\text { Number of } \\
\text { seeds }\end{array}$ & $\begin{array}{c}\text { Juice yield } \\
(\%)\end{array}$ & $\begin{array}{c}\text { Acidity } \\
\left(\mathrm{g} 100 \mathrm{~mL}^{-1}\right)\end{array}$ & $\begin{array}{c}\text { Soluble Solids } \\
\left({ }^{\circ} \text { Brix }\right)\end{array}$ & Ratio \\
\hline TMxLP 16 & 298.0 & 22 & 56.2 & 0.7 & 9.2 & 13.4 \\
\hline
\end{tabular}

Mean of tree samples with six fruits each, harvested in May/2012. 
temperature; once again there was no difference with wax use. This process is due to respiratory metabolism which continues after the harvest, causing various substrates to be used in Krebs cycle. Similar behavior was obtained by Henrique \& Cereda (2007) in reporting a reduction in acidity of Siciliano lemon with increasing storage days and Flores Cantillano et al. (2009) in their postharvest studies with Salustiana oranges under modified atmosphere during cold storage.

The ratio (SS/TA) increased during storage, and after 35 days of storage, independent of the type of storage and use of the wax. It was around 16 compared to 14 at the beginning of the experiment (Figure 4). This increase in the ratio may be due to the increase of sugars in fruits, caused by weight loss, and reduction of acids during

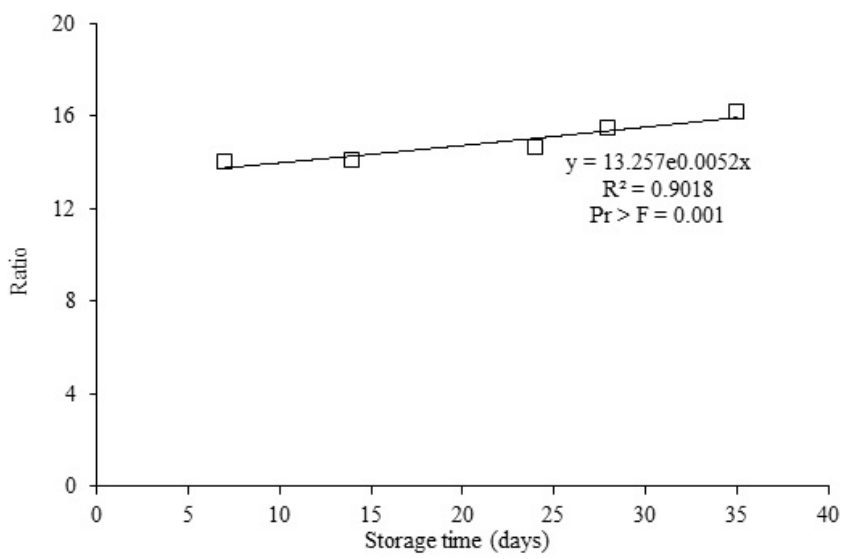

Figure 3. Acidity (\%) concentration of juice, in hybrid TMxLP 16 fruits stored under ambient conditions or under refrigeration for 35 days.

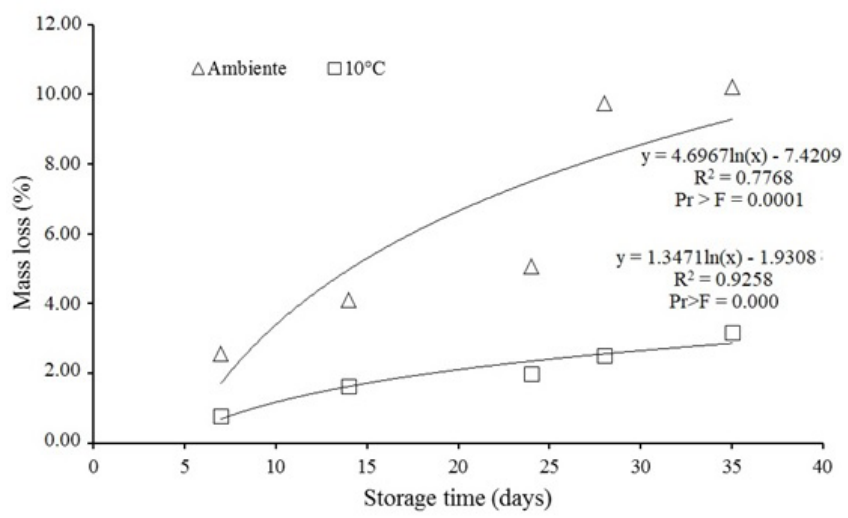

Figure 4. Ratio of juice, in hybrid TMxLP 16 fruits stored under ambient conditions or under refrigeration for 35 days. storage, which is the result of fruits continuous metabolism after harvesting and during storage (Ventura et al., 1992). Rapisarda et al. (2008) worked with five varieties of oranges and observed that SS/TA ratio increased during storage, except for the variety Valencia, whose levels only decreased at the end of the storage period. Already Malgarim et al. (2007) observed that the SS/TA ratio increased during storage, and, when covered with wax the oranges maintained a higher SS/TA ratio. Similarly, Brunini et al. (2013) reported that an increase of the SS/TA ratio in the cultivar (cv.) Hamlin oranges, during storage at different temperatures.

Ceretta et al. (1999) observed that Valencia sweet orange stored under refrigeration at $8{ }^{\circ} \mathrm{C}$, also maintained its physical and chemical quality for up to 42 days. The hybrids of citrus cv. Malgarim et al. (2008) found that hybrids of citrus Nova maintained their postharvest characteristics when stored for 30 days at $8^{\circ} \mathrm{C}$ and $\mathrm{RH}$ of $90-95 \%$. While Brunini et al. (2013) reported that cv. Hamlin sweet orange stored at $11 \pm 1{ }^{\circ} \mathrm{C}$ had shelf life of 21 days. It is noteworthy that the period of refrigerated storage, as well as the temperature used, varies for each citrus cultivar. According to Chitarra \& Chitarra (2005) the optimum temperature conditions for cold storage of orange vary from $3 \pm 2{ }^{\circ} \mathrm{C}$ to $9{ }^{\circ} \mathrm{C} \pm 2{ }^{\circ} \mathrm{C}$, with $\mathrm{RH}$ between $85 \pm 5 \%$ and $90 \pm 5 \%$, where the fruit may be stored for 3 to 8 weeks.

The fruits of the hybrid TMxLP 16 maintained their postharvest quality when stored for 30 days at $10 \pm 2{ }^{\circ} \mathrm{C}$ and relative humidity of $90 \pm 5 \%$ and showed sensory acceptance characteristics with an approval of $93 \%$, being a promising new option for the fresh fruit market.

\section{ACKNOWLEDGEMENTS}

To the Fundação de Amparo à Pesquisa do Estado de São Paulo (Fapesp; process: 2011/18605-0) and Instituto Nacional de Ciência e Tecnologia (INCT, CNPq and Fapesp) de Genômica para Melhoramento de Citros (Process: 573848/2008-4).

\section{REFERENCES}

Agostini, J. S., Scalon, S. P. Q., Lescano, C. H., Silva, K. E., \& Garcete, G. J. (2014). Conservação pós-colheita de laranjas Champagne (Citrus reticulata $\times$ Citrus sinensis). Brazilian Journal of Food Technology, 17, 177-184. 
Beckley, J. H., Foley, M. M., Topp, E. J., Huang, J. C., \& Prinyawiwatkul, W. (2007). Accelerating new food product design and development. Ames: Blackwell Publishing Professional.

Behrens, J. H., Silva, M. A. A. P., \& Wakeling, I. N. (1999). Avaliação da aceitação de vinhos brancos varietais brasileiros através de testes sensoriais afetivos e técnica multivariada de mapa de preferência interno. Food Science and Technology, 19, 214-220.

Brunini, M. A., Samecima Junior, E. H., \& Oliveira, C. A. (2013). Qualidade de laranja Hamlin durante armazenamento em diferentes temperaturas. Nucleus, $10,307-321$.

Ceretta, M., Gonçalves, E. D., Dutra, L. F., Rinaldi, M. M., \& Rombaldi, C. V. (1999). Filme de polietileno e cera na qualidade da laranja 'Valência' frigoarmazenada. Revista Brasileira de Agrociência, 5, 35-37.

Chitarra, M. I. F., \& Chitarra, A. B. (2005). Pós-colheita de frutas e hortaliças: fisiologia e manuseio (785 pp.). Lavras: UFLA.

Flores Cantillano, R. F., Castañeda, L. M. F., Castro, L. A. S., \& Treptow, R. O. (2009). Qualidade pós-colheita de laranjas cv. Salustiana sob atmosfera modificada durante o armazenamento refrigerado (Boletim de Pesquisa e Desenvolvimento Embrapa Clima Temperado, 90, 31 pp.). Brasília: Embrapa Clima Temperado.

Henrique, C. M., \& Cereda, M. P. (2007). Uso de ethephon e fécula de mandioca na conservação pós-colheita de limão 'Siciliano'. Revista de Biologia e Ciências da Terra, 7(1), 99-106.

Janzantti, N. S., Machado, T. V., \& Monteiro, M. (2011). Sensory acceptance of juice from FCOJ processing steps. Journal of Sensory Studies, 26, 322-330.

Lima, M. A., \& Durigan, J. F. (2000). Conservação de goiabas 'Pedro Sato' associando-se refrigeração com diferentes embalagens. Revista Brasileira de Fruticultura, 22, 232-236.

Malgarim, M. B., Flores Cantillano, R. F., Oliveira, R. P., \& Treptow, R. O. (2008). Qualidade pós-colheita de citros 'Nova' em diferentes períodos de armazenamento e comercialização. Revista Brasileira de Agrociência, 14, 19-23.

Malgarim, M. B., Flores Cantillano, R. F., \& Treptow, R. O. (2007). Armazenamento refrigerado de laranjas cv. Navelina em diferentes concentrações de cera à base de carnaúba. Acta Scientiarum. Agronomy, 29, 99-105.

Nascimento, L. M., Cuzin, J., \& Martins, A. B. G. (2006). Efeito do etileno na qualidade de frutos da laranja Pera armazenados sob diferentes temperaturas. Revista Iberoamericana de Tecnología Postcosecha, 8, 7-16.

Rapisarda, P., Bianco, M., Pannuzzo, P., \& Timpanaro, N. (2008). Effect of cold storage on vitamin C, phenolics and antioxidant activity of five orange genotypes [Citrus sinensis (L.) Osbeck]. Postharvest Biology and Technology, 49, 348-354.

Schinor, E. H., Cristofani-Yaly, M., Bastianel, M., \& Machado, M. A. (2010). Caracterização de frutos de híbridos de citros com potencial para a variedade copa. In Anais XXI Congresso Brasileiro de Fruticultura. Natal: Sociedade Brasileira de Fruticultura.

Ventura, M., Ravaglia, G., Sansavini, S., Gorini, F., \& Spada, G. (1992). L'epoca di raccolta come scelta per migliorare la qualità di pesche e nettarine. Rivista di Frutticoltura, 1, 63-67.

Received: February 20, 2017
Accepted: January 10, 2018

How to cite: Pacheco, C. A., Schinor, E. H., Azevedo, F. A., Shimizu, G. D., Bastianel, M., \& Cristofani-Yaly, M. (2018). Sensory acceptance and postharvest quality of a new hybrid of citrus: TMxLP 16. Citrus Research and Technology, 39, e-1031. http://dx.doi.org/10.4322/crt.08315 